Geryk M., Wpływ orientacji uczelni w kierunku społecznej odpowiedzialności na stan finansów

instytucji szkolnictwa wyższego, Przeglad Organizacji, nr 1, 2012, s. 31-34.

Marcin Geryk

Wyższa Szkoła Zarządzania w Gdańsku

Wyższa Szkoła Infrastruktury i Zarządzania w Warszawie

\title{
Wpływ orientacji uczelni w kierunku społecznej odpowiedzialności na stan finansów instytucji szkolnictwa wyższego
}

Słowa kluczowe: rozwój uczelni, finanse, społeczna odpowiedzialność uczelni, zaufanie

\section{Poszukiwanie kierunków rozwoju uczelni}

Obecnie uczelnie stają przed trudnym wyborem możliwych dróg rozwoju. Wielowiekowe doświadczenia okazują się często nie w pełni przydatne w nowoczesnym społeczeństwie wiedzy. Wymagania społeczne w stosunku do instytucji szkolnictwa wyższego są wysokie i ulegają stałym przeobrażeniom.

Uczelnie odwołują się do wartości i zasad mających charakter uniwersalny. Ta, odgrywająca poważną rolę kulturotwórcza, instytucja musi realizować własną strategię rozwoju. Wdrażanie zmian w strategii zarządzania uczelnią napotyka na opór środowisk przywiązanych do tradycyjnej kultury uczelni ${ }^{1}$.

Aby ocenić, jak ważną funkcję pełnią obecnie uczelnie, warto przyjrzeć się opinii S. Fullera, który twierdzi, że „,wiedza stała się obecnie tak istotna, jak praca w klasycznej ekonomii”2. Oznacza to, że instytucje dążące do wiedzy, przyczyniające się do jej upowszechnienia, stanowią o prawdziwej sile światowej gospodarki.

Narastająca presja konkurencyjna współczesnej gospodarki wymusza zmianę orientacji uczelni. Dotyczy to zarówno profili kształcenia, jak i innych aktywności uczelni, np. przyjętych kierunków badań naukowych czy działalności opiniotwórczej, eksperckiej. Dotychczasowa działalność uczelni okazuje się bowiem zbyt tradycyjna, reagująca na zmiany zbyt wolno. Oczywiście trudno zanegować zwyczaj akademicki charakteryzujący się pewną, charakterystyczną

$1 \quad$ J. Woźnicki, Uczelnie akademickie jako instytucje życia publicznego, Fundacja Rektorów Polskich, Warszawa 2007, s. 20-21.

2 S. Fuller, Universities and the Future of Knowledge Governance from the Standpoint of Social Epistemology, http://portal.unesco.org/education/en/ev.php- 
Geryk M., Wpływ orientacji uczelni w kierunku społecznej odpowiedzialności na stan finansów instytucji szkolnictwa wyższego, Przeglad Organizacji, nr 1, 2012, s. 31-34.

powolnością czy statecznością, przydatną w wielu okolicznościach. Tempo zmian, wymuszane przez rewolucję informacyjną, wymaga od uczelni przyjęcia innej perspektywy strategicznej.

W tekście „Światowej Deklaracji UNESCO” proponuje się, że dla podejmowanych prób skutecznego zapewnienia jakości badań naukowych i działalności dydaktycznej niezbędne jest powierzanie funkcji zarządczych osobom posiadającym zarówno doświadczenie menedżerskie, jak i doświadczenie ściśle związane z tradycją akademicką ${ }^{3}$.

Kolejnym czynnikiem wywierającym presję na organizacje edukacyjne jest globalizacja i związany z nią wręcz wspólny, światowy rynek usług wiedzy. Dynamicznie rosnąca wymiana studentów wzmaga presję konkurencyjną. Wymiana osiagnnięć naukowych poddawana jest także ogólnoświatowej konkurencji i dostrzec można kraje, które przykładają do tej wymiany należytą miarę. Szybki marsz chińskich naukowców w rankingu cytowań potwierdza ten trend.

Jednym z proponowanych kierunków rozwoju jest szersze ukierunkowanie działań uczelni, zgodnie z wytycznymi Global Reporting Initiative ${ }^{4}$. Trzy główne zespoły wskaźników: ekonomiczne, środowiskowe i społeczne są próbą systemowego ujęcia procesu działań prospołecznych.

Istnieją dowody potwierdzające, że podejmowanie działań $\mathrm{z}$ zakresu społecznej odpowiedzialności prowadzi do wymiernych ekonomicznie efektów. Warto pamiętać, że takie działania łatwiej zyskują społeczną akceptację, przez co łatwiej osiagnąć zamierzoną pozycję rynkową 5 .

Warto pamiętać o znaczeniu relacji $\mathrm{z}$ interesariuszami, szczególnie $\mathrm{W}$ sytuacji podejmowania działań restrukturyzacyjnych. Podstawowe znaczenie dla powodzenia przyjętego procesu zmian ma ich akceptacja. Docenić należy bowiem powszechną obawę przed jakąkolwiek zmiana status quo ${ }^{6}$.

Wraz z rosnącymi, społecznymi oczekiwaniami wobec organizacji, rośnie świadomość, że długoterminowy rozwój jest niemożliwy bez stworzenia właściwych relacji z interesariuszami. Świadomość długookresowych korzyści narzuca przestrzeganie wielu norm i wartości społecznych, etycznych czy ekologicznych ${ }^{7}$.

3 J. Woźnicki, op.cit., s. 63.

4 The Global Reporting Initiative z siedzibą w Amsterdamie (Królestwo Niderlandów) jest siecią wielu grup interesariuszy, złożoną $\mathrm{z}$ wielu ekspertów. Przygotowują oni wskazówki do raportów. Źródło: www.globalreporting.org/home, ze źródła korzystano 27 lutego $2011 \mathrm{r}$.

5 M. Geryk, Strategie społecznej odpowiedzialności, "Ekonomika i organizacja przedsiębiorstwa" 2010, nr 6 (725), s. 3-11.

6 A. Walecka, Rola restrukturyzacji w sytuacji kryzysu w przedsiębiorstwie, "Studia i Prace Kolegium Zarządzania i Finansów”, zeszyt nr 99, Szkoła Główna Handlowa, Warszawa 2010, s. 231-240.

7 M. Żemigała, Społeczna odpowiedzialność przedsiębiorstwa, Oficyna Wolters Kluwer Polska, Kraków 2007, s. 253. 
A zatem przyjęcie odpowiedniego kierunku kształcenia, zgodnego z przewidywanymi potrzebami przyszłego społeczeństwa stanowi jedno z podstawowych wyzwań instytucji szkolnictwa wyższego. Dzięki skutecznym działaniom w tym zakresie możliwe będzie ukształtowanie nie tylko absolwenta kierującego się w swojej pracy zasadami społecznej odpowiedzialności, ale także pozwoli tworzyć lepszy wizerunek sektora uczelni ${ }^{8}$.

Należy bowiem pamiętać, że wszyscy interesariusze mają wpływ na kierunki rozwoju organizacji. Dążyć należy do upowszechnienia świadomości, że obie sfery działalności podstawowa, związana z realizacją celów statutowych uczelni, jak i społeczna - są ze sobą ściśle powiązane ${ }^{9}$.

Inną cenną wskazówką jest odejście od przyjętego kształcenia wąskiej grupy menedżerów w zakresie przywództwa, kreatywności czy przedsiębiorczości. Wzorem wielu przedsiębiorstw, należy atrybuty te krzewić wśród jak największej grupy studentów. Ta wiedza pozwoli przyszłym absolwentom przetrwać z sukcesem w nowoczesnych organizacjach. Inną rolą uczelni jest pomoc, za pośrednictwem studentów czy późniejszych absolwentów, organizacjom w przyjęciu orientacji społecznej i prowadzenie ,dobrego w rozumieniu etycznym, biznesu”. Przyczynić się to może do znacznie lepszego postrzegania uczelni, a szkół biznesu w szczególności ${ }^{10}$.

Analizując potrzebę przyjęcia przez uczelnie szerszej orientacji społecznej warto podkreślić, że uprawienia nauki czy prowadzenie działalności dydaktycznej prowadzi zarówno do publicznych, jak i prywatnych korzyści. Każdy z elementów wzbogaca drugi, a mnogość korzyści wpływa stymulująco na gospodarkę i jej konkurencyjność. Pozwala to w efekcie odgrywać uczelniom kluczową rolę w społeczeństwie ${ }^{11}$.

\section{Finanse a relacje $\mathrm{z}$ otoczeniem}

Można zakładać, że dojrzalsze związki z otoczeniem to silniejsza marka organizacji. Budowana reputacja organizacji to rezultat zaufania do jej działań. Publikowane informacje w postaci raportów mogą przyspieszyć starania nad kreowaniem pozytywnego, społecznie przyjaznego wizerunku ${ }^{12}$. Tworząc usługi lepiej odpowiadające potrzebom otoczenia, można zatem wpływać pozytywnie na przychody organizacji. Na taką korelację stanu finansów i działalności społecznie odpowiedzialnej

$8 \quad$ M. Geryk, Wptyw działalności uczelni na ksztattowanie społecznie odpowiedzialnych postaw wśród absolwentów [w:] Studia ekonomiczne - czy tyko wiedza i umiejętności?, red. J. Dietl, Z. Sapijaszka, Fundacja Edukacyjna Przedsiębiorczości, Łódź 2008, s. 81-87.

$9 \quad$ J. Adamczyk, Społeczna odpowiedzialność przedsiębiorstw, PWE, Warszawa 2009, s. 76.

10 A. Gabor, Lessons for Business Schools, "strategy+business" 2008, Iss. 50, s. 111-117.

11 P. Clark, The Commercialisation of University Research and Economic Productivity, "Higher Education Management and Policy" 2007, Vol. 19, No. 1, s. 133-144.

12 J. Caby, J.P. Chousa, Voluntary Disclosure of Non-Financial Information and Corporate Social Responsibility [w:] Corporate Social Responsibility. Concepts, Accountability and Reporting, red. J. Allouche, Vol. 1, Palgrave Macmillan, Hampshire - New York 2006, s. 205-218. 
Geryk M., Wpływ orientacji uczelni w kierunku społecznej odpowiedzialności na stan finansów instytucji szkolnictwa wyższego, Przeglad Organizacji, nr 1, 2012, s. 31-34.

wskazują w swoich badaniach J.D. Margolis i J.P. Walsh, twierdząc, że dla ponad połowy badanych istnieje pozytywny związek między aktywnością społecznie odpowiedzialną a wynikiem finansowym, przy założeniu, że wynik finansowy traktujemy jako zmienną zależną. Gdy potraktowano go jako zmienną niezależną, wówczas podobnego zdania było aż 65 proc. badanych $^{13}$.

Dla odbiorców usług coraz istotniejsza okazuje się postawa ich dostarczyciela w zakresie przestrzegania norm etycznych, dotrzymywania składanych obietnic, dbałości o środowisko naturalne czy poziom użyteczności społecznej oferowanych usług. Badania GoodBrand Social Equity Index ${ }^{14}$ dowodzą, że coraz większa liczba odbiorców (56 proc.) oczekuje dbania o środowisko i upośledzone grupy społeczne. Oczywiście walory takie jak cena, jakość, użyteczność pozostają nadal ważne, jednak po kryzysie finansowym zaczęły zyskiwać uznanie konsumentów ${ }^{15}$.

Ważnym zagadnieniem jest relacja ogólnej teorii finansów i pozatechnicznego wymiaru świata gospodarczego. Najistotniejsza jednak jest kwestia, czy teoria finansów może abstrahować od etycznych konsekwencji jej praktycznego zastosowania. Kryteria norm etycznych i zasad społecznej odpowiedzialności powinny być tłem działalności każdej organizacji w zakresie finansów. Prowadzi to do rozwoju usług związanych $\mathrm{z}$ inwestowaniem społecznie odpowiedzialnym. Taka orientacja świadczy o dobrych relacjach instytucji z otoczeniem, o dobrym zarządzaniu wewnętrznym i zewnętrznym i prowadzi do kierowania kapitału w stronę tych działań, które odpowiadają na oczekiwania społeczne ${ }^{16}$.

Zdaniem J. Filek, stopień komplikacji relacji międzyludzkich jest najwyższy w sferze gospodarczej. W wyniku złożoności zachodzącej w na rynkach finansowych dochodzi tamże do największej liczby zaleceń, jak i oczekiwań w zakresie etyki ${ }^{17}$.

Organizacje dążą do umocnienia swojej pozycji rynkowej. Jest to możliwe dzięki skutecznemu gospodarowaniu posiadanymi zasobami. Efektywność zarządzania zasobami stanowi w istocie o przewadze konkurencyjnej ${ }^{18}$. Także autorzy raportu K. Møller i T. Erdal wskazują na

13 J.D. Margolis, J.P. Walsh, Misery Loves Companies: Whither Social Initiatives by Business?, "Harvard Business School Working Paper Series" 2001, No. 01-058, "Social Enterprise Series”, No. 19.

14 GoodBrand Social Equity Index to narzędzie do badania wartości społecznej marek. Zgodnie z nim, marki o wysokim indeksie to te, które prosperują, mają wysoką wartość, a tym samym są szanowane. Klienci częściej je wybierają i są lojalni wybranej marce. Na podstawie http://www.goodbrand.com/pl/insight.html, ze źródła korzystano 2 marca $2011 \mathrm{r}$.

15 P. Niziński, Społeczny wymiar: nowy atut marki, "Harvard Business Review Polska" 2011, marzec, s. s1-s4.

16 W. Gasparski, A. Lewicka-Strzałecka, B. Rok, G. Szulczewski, Etyka w świecie finansów: pojęcia $i$ zagadnienia [w:] Uczciwość w świecie finansów, red. W. Gasparski, Wydawnictwo WSPiZ im. L. Koźmińskiego, Warszawa 2004, s. 28-38.

17 J. Filek, Niektóre przyczyny niskiej etyczności w świecie finansów [w:] Uczciwość w świecie finansów, red. W. Gasparski, Wydawnictwo WSPiZ im. L. Koźmińskiego, Warszawa 2004, s. 127-136.

18 P. Tarka, Wyznaczniki efektywności działalności gospodarczej, "Ekonomika i Organizacja Przedsiębiorstwa" 2010, nr 6 (725), s. 12-19. 
Geryk M., Wpływ orientacji uczelni w kierunku społecznej odpowiedzialności na stan finansów instytucji szkolnictwa wyższego, Przeglad Organizacji, nr 1, 2012, s. 31-34.

„poprawę wyników finansowych” jako jedną z wymiernych korzyści zaangażowania w funkcjonowanie społeczności lokalnej. Innymi korzyściami są poprawa konkurencyjności i lepsza pozycja rynkowa, ale także budowanie wartości niematerialnych, jak korzyści wewnątrzorganizacyjne, lepsza ocena $\mathrm{u}$ szukających pracy czy uznanie otoczenia dla podejmowanych działań ${ }^{19}$. Wszystkie te korzyści w sumie wpływają pozytywnie na wynik finansowy.

\section{Wpływ społecznej odpowiedzialności uczelni na jej finanse}

Koncepcja społecznej odpowiedzialności biznesu stwarza społeczności akademickiej możliwość dokonania pomiaru korzyści z działalności prospołecznej. Dotyczy to ujęcia znacznie szerszego niż tylko korelacje między filantropią a zyskami z działalności ${ }^{20}$.

Klienci, dzięki akceptacji bądź odrzuceniu oferty uczelni, dają jednocześnie wyraz swojego stosunku do działań podejmowanych przez daną instytucję. Z kolei sama organizacja poddaje osądowi społecznemu podejmowane działania, które powinny charakteryzować się wysokim stopniem adaptacji oczekiwań nie tylko w wymiarze ekonomicznym, ale przede wszystkim do idei zrównoważonego rozwoju ${ }^{21}$.

Wiele badań wskazuje na związek między społecznie odpowiedzialną działalnością a zdolnością do generowania zysku. Co więcej, podkreśla się pozytywną korelację między działalnością prospołeczną a poprawą osiąganych wyników finansowych ${ }^{22}$. Ponadto, C.C. Verschoor w wyniku badań przeprowadzonych na 500 największych przedsiębiorstwach w Stanach Zjednoczonych doszedł do wniosku, że firmy przejawiające większą skłonność do działań etycznych czy działań zgodnych z kodeksem etycznym osiągają wyraźnie lepsze wyniki finansowe $e^{23}$. Dodatkowo potwierdzono tezę stawianą w innym badaniu, a zakładająca, że ,zmiana aktywności społecznej jest pozytywnie skorelowana z obecnymi i przyszłymi zmianami wyniku finansowego" 24 .

19 K. Møller, T. Erdal, Corporate responsibility towards society: A local perspective, European Foundation for the Improvement of Living and Working Conditions, Dublin 2003, s. 45-51.

20 L. Burke, J.M. Logsdon, How Corporate Social Responsibility Pays Off [w:] Corporate Social Responsibility. Readings and cases in a global context, red. A. Crane, D. Matten, L. J. Spence, Routledge, London - New York 2008 , s. 420-432.

21 A.G. Scherer, M. Smid, The Downward Spiral and The US Model Business Principles. Why MNEs Should Take Responsibility for The Improvement of World-Wide Social and Environmental Conditions [w:] Corporate Social Responsibility. Readings and cases in a global context, red. A. Crane, D. Matten, L. J. Spence, Routledge, London New York 2008, s. 474-495.

22 B. Anderson, Bringing Business Ethics to Life. Achieving Corporate Social Responsibility, ASQ Quality Press, Milwaukee 2004, s. 13.

23 C.C. Verschoor, A Study of the Link Between a Corporation's Financial Performance and Its Commitment to Ethics, "Journal of Business Ethics" 1998, październik, s. 1509.

24 B.M. Ruf, K. Muralidhar, K. Paul, The Development of a Systematic, Aggregate Measure of Corporate Social Performance, "Journal of Management" 1998, No. 24, s. 119-133. 
Narastające przekonanie, że model działalności nakierowany jedynie na udziałowców jest wysoce niedoskonały, prowadziło do poszukiwania innych podejść. Zainteresowanie modelem uwzględniającym perspektywę interesariuszy, czyli inwestycje społecznie odpowiedzialne, wykazuje obecnie tendencję rosnącą. Wartość aktywów takich funduszy osiągnęła już w 2007 roku ponad 200 mln dolarów ${ }^{25}$.

Oczywiście relacja między społeczną odpowiedzialnością a rynkiem finansowym zależy od alternatywnych źródeł pozyskania kapitału i od zasobności samej organizacji. Inwestycje o przesłaniu społecznie odpowiedzialnym okazują się być dobrym rozwiązaniem dla organizacji, dla których CSR jest spójne ze strategią. Społecznie odpowiedzialne inwestowanie zasobów narzuca stosowanie się do kryteriów etycznych, społecznych i środowiskowych ${ }^{26}$. Adaptacja takich praktyk wpływa na postrzeganie organizacji jako funkcjonującej w sposób mniej ryzykowny i stabilniejszy niż organizacji nie deklarujących społecznej odpowiedzialności ${ }^{27}$.

Zgodnie z danymi Social Investment Forum, w 2010 roku wartość funduszy społecznie odpowiedzialnego inwestowania przekroczyło 3 mld dolarów a w latach 2007-2010 przyrost funduszy przekraczał poziom 13 proc. rocznie. Ponadto, tylko w Stanach Zjednoczonych, działa ponad 250 funduszy tego typu ${ }^{28}$.

Budowanie dobrych relacji z interesariuszami sprzyja nie tylko budowie marki uczelni i lepszemu osadzaniu instytucji w otoczeniu. Podnosi także poziom zaufania, jakim obdarzane są instytucje szkolnictwa wyższego. Ten aspekt okazuje się jedną z najistotniejszych wartości społecznych. Jako klucz do stosunków międzyludzkich zaufanie dotyka wielu przestrzeni badawczych. Przyjęcie właściwej taktyki może być podstawą efektywnej egzystencji na rynku i wpływać pozytywnie na tworzenie pozytywnych relacji ze społeczeństwem ${ }^{29}$.

Można założyć, że strategiczne zintegrowanie zasad społecznej odpowiedzialności z misją i wizją uczelni sprzyjać będzie wzrostowi efektywności wykorzystania zasobów. Oczywiście wymagać to będzie od uczelni zwiększenia reżimu gospodarowania środkami - w przypadku uczelni publicznych dodatkowo środkami budżetowymi. Przykładem takiego rozwiązania może być przyjęcie budżetu zadaniowego, sprzyjającego realizacji założonych celów. Dla usprawnienia

25 J. Becker-Blease, Koncepcja odpowiedzialności biznesu w finansach [w:] Odpowiedzialność biznesu. Teoria $i$ praktyka, red. N.C. Smith, G. Lenssen, Studio EMKA, Warszawa 2009, s. 222-229.

$26 \quad A B C$ of the main instruments of Corporate Social Responsibility, Office for Official Publications of the European Communities, Luxembourg 2004, s. 48.

27 F. Perrini, S. Pogutz, A. Tencati, Developing Corporate Social Responsibility. A European Perspective, Edward Elgar, Cheltenham - Northampton 2006, s. 79.

28 http://www.socialinvest.org/resources/sriguide/srifacts.cfm, ze źródła korzystano 2 marca 2011 r.

29 A. Rudzewicz, E. Zawitowska, Zaufanie w zarządzaniu, "Ekonomika i organizacja przedsiębiorstw” 2010, nr 7 (726), s. 60-66. 
Geryk M., Wpływ orientacji uczelni w kierunku społecznej odpowiedzialności na stan finansów instytucji szkolnictwa wyższego, Przeglad Organizacji, nr 1, 2012, s. 31-34.

procesu zakłada się wprowadzenie ewaluacji zadań budżetowych opartej na miernikach skuteczności i efektywności ${ }^{30}$.

Trudno przecenić rolę zaufania w działalności instytucji szkolnictwa wyższego. W publikacji Edelman Trustbarometer myślą przewodnią raportu za rok 2010 było nawet stwierdzenie, że „zaufanie jest niezbędnym czynnikiem prowadzenia biznesu”. Warto jednocześnie wykorzystywać inne postrzeganie uczelni przez interesariuszy. Są one bowiem zaliczane do przedstawicieli tzw. trzeciego sektora, przez co korzystają z wyższych wskaźników zaufania niż inne instytucje czy organizacje - aż 61 proc. badanych ufa instytucjom trzeciego sektora, że to, co robią, jest słuszne. W tablicy 1 przedstawiono odpowiedzi badanych na pytanie dotyczące hierarchii czynników mających wpływ na reputację firmy ${ }^{31}$.

Tablica 1. Czynniki mające wpływ na reputację firmy

\begin{tabular}{|l|l|}
\hline & \\
\hline Wysoka jakość produktów czy usług & $69 \%$ \\
\hline Przejrzysta praktyka biznesowa & $65 \%$ \\
\hline Opinia, że firma jest godna zaufania & $65 \%$ \\
\hline
\end{tabular}

Źródło: Edelman Trustbarometer 2011. Annual Global Opinion Leaders Study,
http://www.edelman.com/trust/2011/uploads/Edelman\%20Trust\%20Barometer\%20Global\%20Deck.pdf, ze źródła korzystano 2 marca $2011 \mathrm{r}$.

Uczelnie korzystają z ogromnej przewagi. Wysoka społeczna ocena kadry akademickiej sprzyja budowie prospołecznego wizerunku całych instytucji szkolnictwa wyższego. Zaufanie do środowiska obrazują wyniki zamieszczone w tablicy 2.

Tablica 2. Odpowiedzi badanych na pytanie: Jeśli słyszałeś informację o firmie od jednej z poniższych osób, informację od której z osób oceniłbyś jako najbardziej wiarygodną?

\begin{tabular}{|l|l|}
\hline & \\
\hline Ktoś ze środowiska akademickiego lub ekspert & $70 \%$ \\
\hline Ekspert techniczny z danej firmy & $64 \%$ \\
\hline Analityk finansowy lub branżowy & $53 \%$ \\
\hline Źródło Edelman Trustbarometer 2011 Annual Global_ Opinion Leaders Study,
\end{tabular}

Zródło: Edelman Trustbarometer 2011. Annual Global Opinion Leaders Study, http://www.edelman.com/trust/2011/uploads/Edelman\%20Trust\%20Barometer\%20Global\%20Deck.pdf, ze źródła korzystano 2 marca $2011 \mathrm{r}$.

30 E. Walińska, A. Lefik-Szczepańska, Budżetowanie zadaniowe $w$ wyższych szkołach publicznych, "Przegląd Organizacji” 2011, nr 1, s. 24-28.

31 Edelman Trustbarometer 2011. Annual Global Opinion Leaders Study, http://www.edelman.com/trust/2011/uploads/Edelman\%20Trust\%20Barometer\%20Global\%20Deck.pdf, ze źródła korzystano w dniu 2 marca 2011 r. 
Geryk M., Wpływ orientacji uczelni w kierunku społecznej odpowiedzialności na stan finansów instytucji szkolnictwa wyższego, Przeglad Organizacji, nr 1, 2012, s. 31-34.

Oznacza to, że uczelnie powinny w bardziej zdecydowany sposób wykorzystywać posiadane przewagi i odważniej formułować zalecenia i wskazówki związane z kierunkami rozwoju otoczenia. Najważniejsze jest jednak to, że interesariusze takiej właśnie aktywności oczekują, a wysoka ocena społeczna i zaufanie, jakim obdarzają pracowników nauki, tę rangę podkreśla. W konkluzji tegorocznego raportu znalazły się dwa istotne stwierdzenia ${ }^{32}$ :

- Organizacje powinny skojarzyć swój cel działalności i dążenie do zysku z korzyściami społecznymi.

- Zaufanie stanowi ochronę dla organizacji i prowadzi do wymiernych korzyści, zaś brak zaufania stanowi istotną barierę dla dokonywania zmian.

\section{Podsumowanie}

Szkolnictwo wyższe ulega poważnym przeobrażeniom, głównie pod wpływem zmian społecznych i nowych trendów gospodarczych. Funkcjonowanie na coraz bardziej konkurencyjnym rynku usług edukacyjnych szkolnictwa wyższego wymaga sprawnego zarządzania finansami. Optymalne wykorzystanie posiadanych aktywów, także, a w przypadku uczelni - przede wszystkim niematerialnych, może przesądzać o obecnej i przyszłej pozycji rynkowej każdej instytucji.

Przyjęcie orientacji zgodnej $\mathrm{z}$ oczekiwaniami interesariuszy może w wydatny sposób wpłynąć na wzmocnienie marki uczelni poprzez budowę jej reputacji. Postrzeganie uczelni jako instytucji społecznie odpowiedzialnej, jak dowodzą badania, może stymulować wzrost przychodów. Organizacje takie postrzegane są jako wrażliwsze społecznie, a co za tym idzie, lepiej wsłuchujące się w potrzeby otoczenia.

Niezwykle trudno dokonać precyzyjnych pomiarów siły tego oddziaływania na wynik finansowy, jednak wiele przykładów potwierdza pozytywny wpływ. Podstawą jest stworzenie organizacji godnej zaufania, bo tędy wiedzie droga do budowy silnej marki instytucji edukacyjnej. Społeczeństwo oczekuje korzyści, a zatem uznanie i pośrednio impuls wpływający na poprawę sytuacji rynkowej będzie zyskiwała uczelnia, która w potrzeby interesariuszy najzwyczajniej się wsłuchuje.

\section{Literatura}

$A B C$ of the main instruments of Corporate Social Responsibility, Office for Official Publications of the European Communities, Luxembourg 2004.

Adamczyk J., Społeczna odpowiedzialność przedsiębiorstw, PWE, Warszawa 2009.

\footnotetext{
32 Edelman Trustbarometer 2011. Annual Global Opinion Leaders Study, http://www.edelman.com/trust/2011/uploads/Edelman\%20Trust\%20Barometer\%20Global\%20Deck.pdf, ze źródła korzystano w dniu 2 marca 2011 r.
} 
Anderson B., Bringing Business Ethics to Life. Achieving Corporate Social Responsibility, ASQ Quality Press, Milwaukee 2004.

Becker-Blease J., Koncepcja odpowiedzialności biznesu w finansach [w:] Odpowiedzialność biznesu. Teoria i praktyka, red. N.C. Smith, G. Lenssen, Studio EMKA, Warszawa 2009.

Burke L., Logsdon J.M., How Corporate Social Responsibility Pays Off [w:] Corporate Social Responsibility. Readings and cases in a global context, red. A. Crane, D. Matten, L. J. Spence, Routledge, London - New York 2008.

Caby J., Chousa J.P., Voluntary Disclosure of Non-Financial Information and Corporate Social Responsibility [w:] Corporate Social Responsibility. Concepts, Accountability and Reporting, red. J. Allouche, Vol. 1, Palgrave Macmillan, Hampshire - New York 2006.

Clark P., The Commercialisation of University Research and Economic Productivity, "Higher Education Management and Policy" 2007, Vol. 19, No. 1.

Edelman Trustbarometer 2011. Annual Global Opinion Leaders Study, http://www.edelman.com/trust/2011/uploads/Edelman\%20Trust\%20Barometer\%20Global\%20Deck.pdf, $\quad$ ze źródła korzystano w dniu 2 marca $2011 \mathrm{r}$.

Filek J., Niektóre przyczyny niskiej etyczności w świecie finansów [w:] Uczciwość w świecie finansów, red. W. Gasparski, Wydawnictwo WSPiZ im. L. Koźmińskiego, Warszawa 2004.

Fuller S., Universities and the Future of Knowledge Governance from the Standpoint of Social Epistemology, http://portal.unesco.org/education/en/ev.php-

URL_ID=35262\&URL_DO=DO_PRINTPAGE\&URL_SECTION=201.html, ze źródła korzystano 2 marca $2011 \mathrm{r}$.

Gabor A., Lessons for Business Schools, "strategy+business" 2008, Iss. 50.

Gasparski W., Lewicka-Strzałecka A., Rok B., Szulczewski G., Etyka w świecie finansów: pojęcia i zagadnienia [w:] Uczciwość w świecie finansów, red. W. Gasparski, Wydawnictwo WSPiZ im. L. Koźmińskiego, Warszawa 2004.

Geryk M., Strategie spotecznej odpowiedzialności, "Ekonomika i organizacja przedsiębiorstwa” 2010, nr 6 (725).

Geryk M., Wpływ działalności uczelni na kształtowanie społecznie odpowiedzialnych postaw wśród absolwentów [w:] Studia ekonomiczne - czy tyko wiedza i umiejętności?, red. J. Dietl, Z. Sapijaszka, Fundacja Edukacyjna Przedsiębiorczości, Łódź 2008.

Margolis J.D., Walsh J.P., Misery Loves Companies: Whither Social Initiatives by Business?, "Harvard Business School Working Paper Series" 2001, No. 01-058, "Social Enterprise Series", No. 19.

Møller K., Erdal T., Corporate responsibility towards society: A local perspective, European Foundation for the Improvement of Living and Working Conditions, Dublin 2003.

Niziński P., Społeczny wymiar: nowy atut marki, "Harvard Business Review Polska" 2011, marzec.

Perrini F., Pogutz S., Tencati A., Developing Corporate Social Responsibility. A European Perspective, Edward Elgar, Cheltenham - Northampton 2006.

Rudzewicz A., Zawitowska E., Zaufanie w zarządzaniu, “Ekonomika i organizacja przedsiębiorstw” 2010, nr 7 (726).

Ruf B.M., Muralidhar K., Paul K., The Development of a Systematic, Aggregate Measure of Corporate Social Performance, "Journal of Management" 1998, No. 24.

Scherer A.G., Smid M., The Downward Spiral and The US Model Business Principles. Why MNEs Should Take Responsibility for The Improvement of World-Wide Social and Environmental Conditions [w:] Corporate Social Responsibility. Readings and cases in a global context, red. A. Crane, D. Matten, L. J. Spence, Routledge, London New York 2008.

Tarka P., Wyznaczniki efektywności działalności gospodarczej, "Ekonomika i Organizacja Przedsiębiorstwa” 2010, nr 6 (725).

Verschoor C.C., A Study of the Link Between a Corporation's Financial Performance and Its Commitment to Ethics, "Journal of Business Ethics" 1998, październik.

Walecka A., Rola restrukturyzacji w sytuacji kryzysu w przedsiębiorstwie, "Studia i Prace Kolegium Zarządzania i Finansów", zeszyt nr 99, Szkoła Główna Handlowa, Warszawa 2010.

Walińska E., Lefik-Szczepańska A., Budżetowanie zadaniowe $w$ wyższych szkołach publicznych, "Przegląd Organizacji" 2011, nr 1.

Woźnicki J., Uczelnie akademickie jako instytucje życia publicznego, Fundacja Rektorów Polskich, Warszawa 2007.

Żemigała M., Społeczna odpowiedzialność przedsiębiorstwa, Oficyna Wolters Kluwer Polska, Kraków 2007.

http://www.globalreporting.org/home, ze źródła korzystano 27 lutego $2011 \mathrm{r}$.

http://www.goodbrand.com/pl/insight.html, ze źródła korzystano 2 marca $2011 \mathrm{r}$.

http://www.socialinvest.org/resources/sriguide/srifacts.cfm, ze źródła korzystano 2 marca $2011 \mathrm{r}$. 